研究

\title{
溶液プロセスによるアルカリ金属を含む $\mathrm{TiO}_{2}$ 系複合酸化物微粒子の低温作製
}

\author{
小林めぐみ，藤本憲次郎，伊藤＼cjkstart滋 \\ 東京理科大学理工学部工業化学科, ₹ 278-8510 野田市山崎 2641.
}

\section{Low-Temperature Preparation of Nano-Sized Particles of Some Alkali Titanates by Solution Process}

\author{
Megumi Kobayashi, Kenjiro Fujimoto and Shigeru Ito \\ Department of Pure and Applied Chemistry, Faculty of Science and Technology, Tokyo University of Science, Noda 278-8510, Japan.
}

Received November 10, 2008

\section{SYNOPSIS}

Alkali ions were co-precipitated with titanium hydroxide gels. When $\mathrm{Ti}\left(\mathrm{SO}_{4}\right)_{2}$ solution was added to $\mathrm{KOH}$ solution with $\mathrm{K}: \mathrm{Ti}=10: 1$ (in molar ratio), the potassium remains in the precipitated gel, in spite of several times of washing. Excess amount of alkali and $\mathrm{pH}>9$ were the essential conditions for the co-precipitation. Similar results were obtained for the other alkali elements; $\mathrm{Li}$ and $\mathrm{Na}$. Nano-sized particles of $\mathrm{K}_{2} \mathrm{O}-6 \mathrm{TiO}_{2}, \mathrm{Li}_{2} \mathrm{O}-\mathrm{TiO}_{2}$ and $\mathrm{Na}_{2} \mathrm{O}-3 \mathrm{TiO}_{2}$ with $20-30 \mathrm{~nm}$ in size were respectively obtained by heating the precipitates at 500 or $600^{\circ} \mathrm{C}$.

In addition, the thin films of alkali titanates were obtained on $\mathrm{Si}$ substrate by dripping $\mathrm{Ti}\left(\mathrm{SO}_{4}\right)_{2}$ solution and MOH solution for 30-60 min.

\section{KEY WORDS}

solution process, nano-sized particles, titanate, alkali metal elements

\section{1 緒 言}

一般的に金属酸化物微粒子もしくは薄膜の作製には高温を 要することが多く，多大なエネルギーを必要とする.これに 対して, 我々は以前から原料溶液を直接基板上に滴下し, 薄 膜を作製する“溶液プロセス”を用いて，室温または $100^{\circ} \mathrm{C}$ 以下の低温で $\mathrm{TiO}_{2}, \mathrm{SnO}_{2}, \mathrm{SiO}_{2}$ 等の単成分系酸化物薄膜の作製 を試みてきた。しかしながら，この溶液プロセスでは，チ夕 ン酸バリウムやチタン酸アルカリのような 2 成分系酸化物薄 膜を作製することは困難であった．例えば，これまでに $\mathrm{TiO}_{2}$ 薄膜が水酸化ナトリウム溶液と硫酸チタン溶液を直接基板上 に滴下する方法で作製された。すなわち，この2液を滴下直 後に反応させることで, 基板上に微細な粒子が堆積し，アモ ルファス $\mathrm{TiO}_{2}(\mathrm{OH}$ 基または水を含む) 薄膜を作製することが 出来た ${ }^{1)}$. これは, 水酸化アルカリと硫酸チタンまたは塩化 チタンを基板上に滴下し，反応させると(1) 式のように反応 し， $\mathrm{TiO}_{2}$ 薄膜が生成されたためである，この方法により，一 部アナターゼ化した $\mathrm{TiO}_{2}$ を含む非晶質の粉末が得られてい る.

$$
\mathrm{Ti}\left(\mathrm{SO}_{4}\right)_{2}+4 \mathrm{NaOH} \rightarrow \mathrm{TiO}_{2}+2 \mathrm{Na}_{2} \mathrm{SO}_{4}+2 \mathrm{H}_{2} \mathrm{O}
$$

このように, アルカリは溶液中に残る、すなわち, 水酸化ア ルカリで沈殿させると水酸化物(オキソ酸)が得られるが, チ タン酸アルカリのようなアルカリ金属を含んだ沈殿物は生成 しない，一般に水溶液からアルカリ金属を含む固体化合物を つくることは困難である.このことから, 溶液プロセスを用 いた薄膜作製は単成分系において適用可能であるが, アルカ リ金属を含む 2 成分系薄膜作製には至っていない.したがっ て, まず水溶液からアルカリ金属を含む共沈物質または複合 酸化物を作製することは，溶液プロセスの適用範囲を 2 成分 系薄膜にまで広げるための重要なデータとなる. 複合酸化物 の中でも, 含アルカリ化合物は $\mathrm{LiCoO}_{2}$ をばめとした電池材

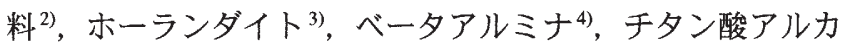
リなど, 有用なものが多い. 本研究ではチタン酸アルカリに 着目した. $\mathrm{M}_{2} \mathrm{Ti}_{\mathrm{n}} \mathrm{O}_{2 \mathrm{n}+1}(\mathrm{M}=$ アルカリ金属)で表されるチタン酸 アルカリは $\mathrm{n}=3,4$ でインターカレーション能, 触媒活性を持つ 層状構造を成し, $\mathrm{n}=6,7,8$ で, 化学的に安定なトンネル構造 を成す ${ }^{5-9,14)}$. 特に繊維状の $\mathrm{K}_{2} \mathrm{Ti}_{6} \mathrm{O}_{13}$ は断熱材，イオン交換体， プラスチックおよびセラミックなどの強化に用いられる またチタン酸ナトリウムは電位差測定センサーの酸素電極と しての研究がされており ${ }^{13,17)}$ ，チタン酸リチウムは核融合炉 
のトリチウム增殖材料のための低放射化セラミック材料の代 替品として研究されている15,16). しかし，その作製プロセス は固相合成や水熱法など高温もしくは高圧を要するものであ る.これに対して，我々が以前から試みてきた溶液プロセス による酸化物の作製法を用い，低温でアルカリを含む共沈物 質または複合酸化物が作製できれば, 先に述べた溶液プロセ スによる2成分系薄膜作製のための重要なデー夕になるばか りでなく,チタン酸アルカリ酸化物の作製プロセスの簢略化, 低エネルギー化が期待できる.

本研究では, まず $\mathrm{MOH}$ 水溶液と $\mathrm{Ti}\left(\mathrm{SO}_{4}\right)_{2}$ 水溶液を反応さ せ, チタン酸アルカリ沈殿物を作製するためにアルカリ金属 がチタンを含む固相に含まれる条件を探った. ついで, チタ ン酸アルカリ酸化物微粒子の低温作製を行う目的で, 固相中 のアルカリの組成, 低温焼成時の生成物について調べた. ま た，得られた条件を基にして，Si 基板上に原料溶液を滴下す る方法により, 低温における薄膜化についても検討した.

\section{2 実験方法}

室温において, $1.0 \mathrm{~mol} / \mathrm{L}$ 水酸化カリウム (和光純薬工業株 式会社, 特級) 水溶液 $100 \mathrm{~mL}$ 中に $1.0 \times 10^{-1} \mathrm{~mol} / \mathrm{L}$ 硫酸チタン (関東化学株式会社, 鹿 1 級) 水溶液 $50 \sim 100 \mathrm{~mL}$ を混合し, 沈 殿物を生成させた. 混合後の溶液の $\mathrm{pH}$ を測定した後, 遠心 分離機 (KOKUSAN 製 H-103N (回転数 1500 rpm)) で 20 分間, 沈殿を分離した. 分離後に上澄みを除去し，新たに蒸留水を 加えて, この操作を 3 回繰り返し, 沈殿物を洗浄した. 得ら れた沈殿物の一部を自然乾燥した後, 乳鉢で粉砕し,アルミ ナ製のボートにのせ, 電気炉を用いて $200 \sim 1000^{\circ} \mathrm{C}$ の所定温 度で 4 時間熱処理した. その後, 粉末 X 線回折装置 ( 理学電 気製 MINIFLEX) を用いて, XRD パターンを得た。 自然乾燥 させた $\mathrm{K}_{2} \mathrm{O}-\mathrm{TiO}_{2}$ 系沈殿物を ICP (Inductively Coupled Plasma) 発光分光分析装置 (島津製ICPS-7500) を用いて分析し, K, Ti の組成を求めた. さらに自然乾燥した後の沈殿物の熱重量測 定(TG-DTA，マック・サイエンス侏製2000S)を昇温速度 $5^{\circ} \mathrm{C} /$ $\min , 800^{\circ} \mathrm{C}$ まで行った. また, 走查型電子顕微鏡 (SEM, 日本 電子(侏製 JSM-5500，日立製作所製 S-5000)により試料の微構 造の観察を行った. 別に原料に水酸化リチウム (MERCK, 特 級), 水酸化ナトリウム (関東化学株式会社, 特級) を用いて 同様に実験した.

\section{3 結果および考察}

3.1 溶液の混合による含アルカリ沈殿物の作製

まず, $\mathrm{Ti}\left(\mathrm{SO}_{4}\right)_{2}$ 溶液に $\mathrm{KOH}$ 溶液を加えて混合した場合およ び混合溶液が酸性を示した場合に, 得られた沈殿物を $1000^{\circ} \mathrm{C}$ で4時間熱処理した後, 粉末 X線回折法により生成物を同定 すると, $\mathrm{TiO}_{2}$ (アナターゼ) と $\mathrm{K}_{2} \mathrm{SO}_{4}$ を生じた.すなわち, 混合 直後の反応として, $\mathrm{K}_{2} \mathrm{SO}_{4}$ とチタンの水和物が得られること が明らかになった. そこで, 水に可溶性の $\mathrm{K}_{2} \mathrm{SO}_{4}$ は沈殿物の 洗净を 3 回繰り返すことで除去した．この洗净により，Kが 流れて出てしまうことを考慮し, KOHを過剩に混合する必要
があった。ささに, $\mathrm{KOH}$ 溶液に $\mathrm{Ti}\left(\mathrm{SO}_{4}\right)_{2}$ 溶液を滴下していく 方法で溶液を混合した. Table 1 に $\mathrm{Ti}\left(\mathrm{SO}_{4}\right)_{2}$ 溶液と $\mathrm{KOH}$ 溶液 を混合した後の $\mathrm{pH}$ とその際の沈殿物の組成を示す．Table 1 に示すように, 混合溶液の $\mathrm{pH}$ が酸性の値を示した場合, Tiの みを含む沈殿物を生じた. Ti とKを含む沈殿物を生じたのは, 混合溶液が $\mathrm{pH}$ 9以上のアルカリ性を示した場合であった.こ のとき, $\mathrm{Ti}\left(\mathrm{SO}_{4}\right)_{2}$ 溶液の濃度は $0.1 \mathrm{~mol} / \mathrm{L}, \mathrm{KOH}$ 溶液の濃度は $1 \mathrm{~mol} / \mathrm{L}$ であり, モル比 $\mathrm{Ti}: \mathrm{K}=1: 10$ と $\mathrm{K}$ が大過剩の場合で あった. すなわち, $\mathrm{Ti}\left(\mathrm{SO}_{4}\right)_{2}$ 溶液に比べて $\mathrm{KOH}$ 溶液が 10 倍 (モル比)とかなり過剩であれば, K とTiを含む沈殿物を生成 することができた，したがって，溶液を常にアルカリ性に保 つことが $\mathrm{K}$ 含む沈殿を作製するためには重要である.この 沈殿物は, 水で 3 回洗浄した後のものであり, $\mathrm{K}$ はこの沈殿 物と物理吸着ではなく，なんらかの化学吸着をしているもの と思われる.これらのことから以下の実験では溶液のアルカ リ性を保持するために, 過剩の $\mathrm{KOH}$ 溶液に $\mathrm{Ti}\left(\mathrm{SO}_{4}\right)_{2}$ 溶液を滴 下する方法で溶液の混合を行った. また, $\mathrm{M}=\mathrm{Li}$ の場合は $\mathrm{pH}$ 10.1 のとき $\mathrm{Li} / \mathrm{Ti}=0.91, \mathrm{pH} 11.58$ のとき $\mathrm{Li} / \mathrm{Ti}=0.90$ となり, $\mathrm{M}=\mathrm{Na}$ の場合は $\mathrm{pH} 10.0$ のとき $\mathrm{Na} / \mathrm{Ti}=0.77$ という結果が得ら れた.いずれの場合も混合溶液が $\mathrm{pH} 10$ 以上のアルカリ性を 示した場合であった.

$3.2 \mathrm{~K}_{2} \mathrm{O}-\mathrm{TiO}_{2}$ 系微粒子の作製

沈殿物の加熱による結晶化について調べるため, TG-DTA 測定および粉末 X線回折法により, 沈殿物を熱処理した後に 得られる生成物の同定を行った. Fig. 1 に $\mathrm{pH} 10.0$ の溶液から 得られた沈殿物の TG-DTA曲線を示す.なお, TG-DTA測定 は昇温速度 $5^{\circ} \mathrm{C} / \mathrm{min}$ で $800^{\circ} \mathrm{C}$ まで行った。 まず $\mathrm{TG}$ 曲線に着

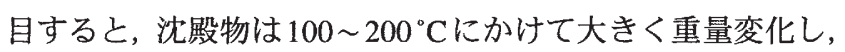
$800^{\circ} \mathrm{C}$ に加熱後では, $24 \%$ 重量減少した. また, DTA曲線に よると, $100 \sim 200^{\circ} \mathrm{C} に$ 見られる吸熱ピークは明らかに脱水に よるものであり, 400 $500^{\circ} \mathrm{C}$ にかけて結晶化と思われる発熱 ピークが見られた.すなわち，この沈殿物は $100 \sim 200^{\circ} \mathrm{C}$ の 加熱で付着水や水和水が取り除かれ，500 ${ }^{\circ} \mathrm{C}$ の熱処理でほと んどのアモルファス相が結晶化すると考えられる. Fig.2に同 じく $\mathrm{pH} 10.0$ の溶液から得られた試料の各所定温度における

Table 1 Composition of $\mathrm{K} / \mathrm{Ti}$ in the precipitates obtained from $\mathrm{KOH}$ and $\mathrm{Ti}\left(\mathrm{SO}_{4}\right)_{2}$ solutions.

\begin{tabular}{|c|c|}
\hline $\mathrm{pH}$ after mixing & $\mathrm{K} / \mathrm{Ti}$ \\
\hline 2.7 & 0 \\
\hline 5.0 & 0 \\
\hline 9.4 & 0.88 \\
\hline 10.0 & 1.1 \\
\hline 11.2 & 1.1 \\
\hline 12.3 & 1.8 \\
\hline
\end{tabular}




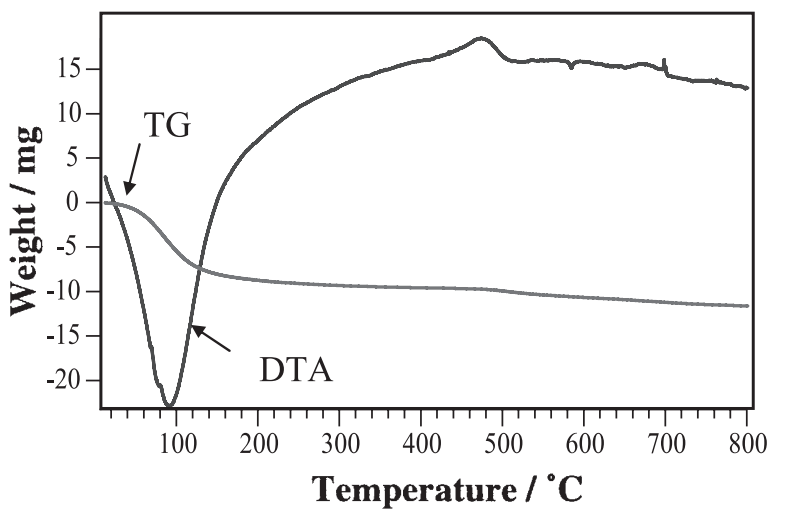

Fig.1 TG-DTA curves for the $\mathrm{K}_{2} \mathrm{O}-\mathrm{TiO}_{2}$ precipitate obtained at room temperature.

Precipitation parameters;

$\mathrm{Ti}\left(\mathrm{SO}_{4}\right)_{2}$ solution: $0.1 \mathrm{~mol} / \mathrm{L}, 100 \mathrm{~mL}$

$\mathrm{KOH}$ solution: $1.0 \mathrm{~mol} / \mathrm{L}, 100 \mathrm{~mL}$

pH after mixing: 10.0

TG-DTA measurement;

Sample weight: $48.5 \mathrm{mg}$

Heating up to $800^{\circ} \mathrm{C}$ with $5^{\circ} \mathrm{C} / \mathrm{min}$.

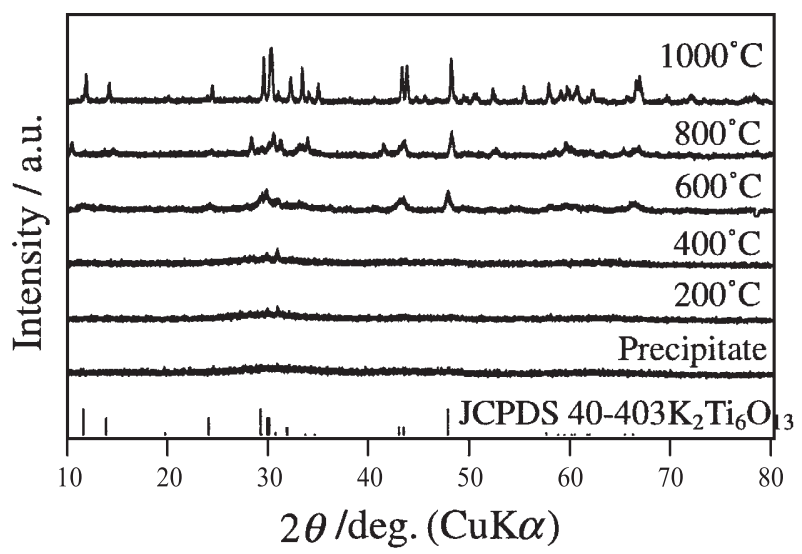

Fig.2 XRD patterns for the $\mathrm{K}_{2} \mathrm{O}-\mathrm{TiO}_{2}$ precipitate after heating at different temperatures.

Precipitation parameters:

$\mathrm{Ti}\left(\mathrm{SO}_{4}\right)_{2}$ solution: $0.1 \mathrm{~mol} / \mathrm{L}, 100 \mathrm{~mL}$

$\mathrm{KOH}$ solution: $1.0 \mathrm{~mol} / \mathrm{L}, 100 \mathrm{~mL}$

$\mathrm{pH}$ after mixing: 10.0

熱処理後の粉末 $\mathrm{X}$ 線回折パターンを示す. $1000^{\circ} \mathrm{C}$ の加熱後, 試料の主生成物は, $\mathrm{K}_{2} \mathrm{O}-6 \mathrm{TiO}_{2}$ (JCPDS40-403) と同定された. 3-1で述べたように，沈殿物の組成は $\mathrm{K} / \mathrm{Ti}=1.1$ であるが，熱 処理の主生成物の組成は $\mathrm{K} / \mathrm{Ti}=1 / 3$ となっており, 異なってい る.このことから, 余ったカリウムがなんらかの化合物とし て沈殿物中に存在している可能性がある. 実際に, 不純物と して $200,400^{\circ} \mathrm{C}$ のRD 図形で $30^{\circ}$ 付近に見られるピークは $\mathrm{K}_{2} \mathrm{CO}_{3}$ のもので, $800^{\circ} \mathrm{C}$ で六方晶の $\mathrm{K}_{2} \mathrm{SO}_{4}$ と思われるピーク が見られた. 本研究では沈殿物を空気中で合成および熱処理 したことから, 沈殿物が空気中の $\mathrm{CO}_{2}$ と反応し $\mathrm{K}_{2} \mathrm{CO}_{3}$ が生成 したと考えられる.なお， 3.1 で得られた $\mathrm{pH} 9.4$ 以上の $\mathrm{Ti}$ と $\mathrm{K}$ を含む他の沈殿物においても $1000^{\circ} \mathrm{C}$ 加熱後には $\mathrm{K}_{2} \mathrm{Ti}_{6} \mathrm{O}_{13}$ が 得られた. Bao 等の報告によると, 固相合成において, モル
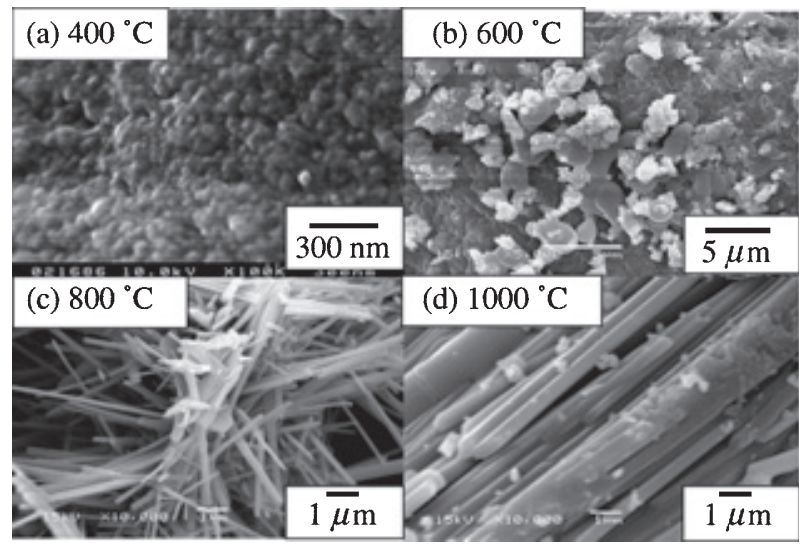

Fig.3 SEM images of the $\mathrm{K}_{2} \mathrm{O}-\mathrm{TiO}_{2}$ precipitate after heating at different temperatures for $4 \mathrm{~h}$.

Precipitation parameters:

$\mathrm{Ti}\left(\mathrm{SO}_{4}\right)_{2}$ solution: $0.1 \mathrm{~mol} / \mathrm{L}, 100 \mathrm{~mL}$ $\mathrm{KOH}$ solution: $1.0 \mathrm{~mol} / \mathrm{L}, 100 \mathrm{~mL}$ pH after mixing: 10

比 $\mathrm{TiO}_{2} / \mathrm{K}_{2} \mathrm{O}=3$ の混合比で作製した場合, 熱処理温度 $830^{\circ} \mathrm{C}$ で $\mathrm{K}_{2} \mathrm{Ti}_{2} \mathrm{O}_{5}, 960^{\circ} \mathrm{C}$ で $\mathrm{K}_{2} \mathrm{Ti}_{4} \mathrm{O}_{9}, 1130^{\circ} \mathrm{C}$ で $\mathrm{K}_{2} \mathrm{Ti}_{6} \mathrm{O}_{13}$ と温度よっ て主生成物は異なっている。これは固相反応では 2 つ上の 固体反応物微粒子が互いに接触し，その接触点からイオンが 拡散して反応物が生成するため, 焼成温度や原料の混合比に よって生成物が異なる.このため一般的に固相合成において 組成的均一性が低いことが知られている. 本研究では, $\mathrm{K}_{2} \mathrm{O}$ $\mathrm{TiO}_{2}$ 系沈殿物は $\mathrm{K}_{2} \mathrm{O}-6 \mathrm{TiO}_{2}$ となり得る前駆体粉末以外に生成 せず, 残りの $\mathrm{K} は \mathrm{~K}_{2} \mathrm{CO}_{3}$ 等の化合物となって存在することが 示唆された. Fig.3に同じく pH 10.0 の溶液から得られた試料 の熱処理後の SEM 写真を示す. $400^{\circ} \mathrm{C}$ の熱処理でおよそ 30 $\mathrm{nm}$ の粒子が観察され, $1000^{\circ} \mathrm{C}$ の熱処理の結果, 六チタン酸 カリウムの晶癖である繊維状に成長した。 $\mathrm{K}_{2} \mathrm{O}-6 \mathrm{TiO}_{2}$ は一般 的に六チタン酸カリウムと呼ばれる繊維状の複合酸化物であ り, 先に述べたようにプラスチックの強化, 断熱材として研 究されてきた. 最近では $\mathrm{K}_{2} \mathrm{O}-6 \mathrm{TiO}_{2}$ ナノワイヤーを作製し, 太陽電池や光触媒としての可能性を示唆した報告がある ${ }^{17)}$. 作製法としては $\mathrm{TiO}_{2}$ と $\mathrm{K}_{2} \mathrm{CO}_{3}$ からの固相合成の他に, $\mathrm{TiO}_{2}$ ナ ノ粉末と $\mathrm{KOH}$ を用いた水熱法での作製 ${ }^{10)}, \mathrm{Na}_{2} \mathrm{Ti}_{3} \mathrm{O}_{7}$ と $\mathrm{KOH}$ を用いた水熱法での作製 ${ }^{12)}$ が報告されている. しかし本研究 のような水溶液から比較的低温で作製する例は他にない.

以上, 過㮃な量の $\mathrm{KOH}$ 溶液に $\mathrm{Ti}\left(\mathrm{SO}_{4}\right)_{2}$ 溶液を加えることで, $\mathrm{K}$ を含んだ中間生成物が得られた。これを $500^{\circ} \mathrm{C} て ゙$ 加熱する ことより， $\mathrm{K}_{2} \mathrm{O}-6 \mathrm{TiO}_{2}$ を主生成物とするナノサイズの粒子を 作製することができた.

$3.3 \mathrm{Li}_{2} \mathrm{O}-\mathrm{TiO}_{2}$ 系微粒子の作製

$\mathrm{K}_{2} \mathrm{O}-\mathrm{TiO}_{2}$ 系と同様, 沈殿物の加熱による結晶化について調 ベるため, TG-DTA測定および粉末 X線回折法により, 沈殿 物の熱処理後に得られる生成物の同定を行った. Fig.4に $\mathrm{pH}$ 11.8 の混合溶液から得られた沈殿物の TG-DTA曲線を示す. まず TG曲線に着目すると, $\mathrm{M}=\mathrm{K}$ と同様に, 沈殿物は 100 $200^{\circ} \mathrm{C}$ にかけて大きく重量変化し, $800^{\circ} \mathrm{C}$ に加熱後では, $22 \%$ 


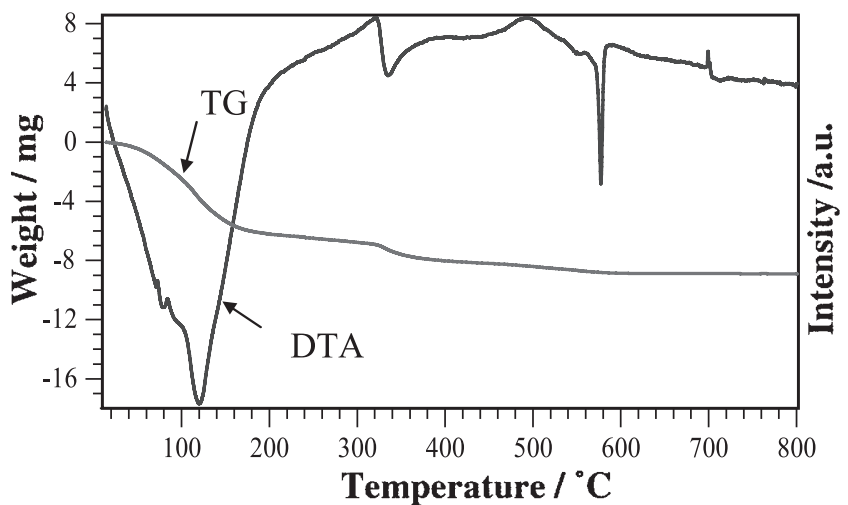

Fig.4 TG-DTA curves for the $\mathrm{Li}_{2} \mathrm{O}-\mathrm{TiO}_{2}$ precipitate obtained at room temperature.

Precipitation parameters:

$\mathrm{Ti}\left(\mathrm{SO}_{4}\right)_{2}$ solution: $0.1 \mathrm{~mol} / \mathrm{L}, 100 \mathrm{~mL}$

$\mathrm{LiOH}$ solution: $1.0 \mathrm{~mol} / \mathrm{L}, 100 \mathrm{~mL}$

pH after mixing: 11.8

TG-DTA measurement;

Sample weight: $40.0 \mathrm{mg}$

Heating up to $800^{\circ} \mathrm{C}$ with $5^{\circ} \mathrm{C} / \mathrm{min}$.

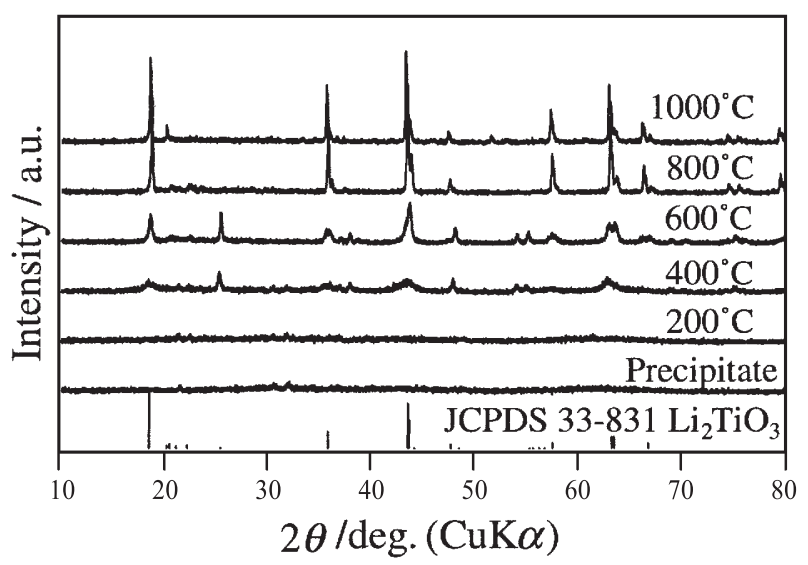

Fig.5 XRD patterns for the $\mathrm{Li}_{2} \mathrm{O}-\mathrm{TiO}_{2}$ precipitate after heating at different temperatures.

Precipitation parameters:

$\mathrm{Ti}\left(\mathrm{SO}_{4}\right)_{2}$ solution: $0.1 \mathrm{~mol} / \mathrm{L}, 100 \mathrm{~mL}$

$\mathrm{LiOH}$ solution: $1.0 \mathrm{~mol} / \mathrm{L}, 100 \mathrm{~mL}$

pH after mixing: 11.8

重量減少した。 また, DTA 曲線によると, $100 \sim 200^{\circ} \mathrm{C}$ 見 られる吸熱ピークは明らかに脱水によるものであり， $340^{\circ} \mathrm{C}$ 付近に見られるピークは $\mathrm{OH}$ 基の脱離によるものと考えられ る. 400 500 ${ }^{\circ} \mathrm{C}$ 加けて結晶化と思われる発熱ピークが確認 できる.すなわち，この沈殿物は $100 \sim 200^{\circ} \mathrm{C}$ の加熱で付着 水や水和水, $340^{\circ} \mathrm{C}$ 付近で $\mathrm{OH}$ 基が取り除かれ, $500^{\circ} \mathrm{C}$ の熱処 理でほとんどのアモルファス相が結晶化すると考えられる. Fig.5に同じく pH 11.8の混合溶液から得られた沈殿物を各所 定温度で熱処理した後の粉末 $\mathrm{X}$ 線回折パターンを示す. $1000^{\circ} \mathrm{C}$ 加熱後の試料の主生成物は $\mathrm{Li}_{2} \mathrm{TiO}_{3}$ (JCPDS33-831) と同定され た.また Fig. 5 の $400,600^{\circ} \mathrm{C}$ の $25^{\circ}$ 付近のピ一クは $\mathrm{TiO}_{2}$ (アナ ターゼ)のものであった. ICP分析結果から, 熱処理前の沈殿 物の組成は $\mathrm{Li} / \mathrm{Ti}=1$ となったのに対し, $1000^{\circ} \mathrm{C}$ 加熱後の主生

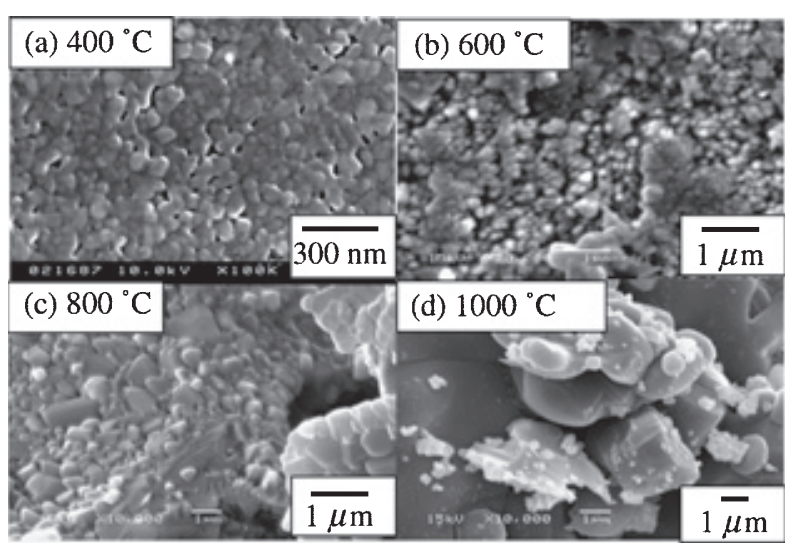

Fig.6 SEM images of the $\mathrm{Li}_{2} \mathrm{O}-\mathrm{TiO}_{2}$ precipitate after heating at different temperatures for $4 \mathrm{~h}$.

Precipitation parameters:

$\mathrm{Ti}\left(\mathrm{SO}_{4}\right)_{2}$ solution: $0.1 \mathrm{~mol} / \mathrm{L}, 100 \mathrm{~mL}$

LiOH solution: $1.0 \mathrm{~mol} / \mathrm{L}, 100 \mathrm{~mL}$ pH after mixing: 11.8

成物は $\mathrm{Li} / \mathrm{Ti}=2$ の $\mathrm{Li}_{2} \mathrm{TiO}_{3}$ であったことからも, 沈殿物にはLi と反応しなかった $\mathrm{Ti}$ が $\mathrm{TiO}_{2}$ として存在していたと考えられ る. $\mathrm{Li}_{2} \mathrm{TiO}_{3}$ は, 核融合炉ブランケット用トリチウム增殖材料 として注目されている材料である ${ }^{15)}$. 作製法については, $\mathrm{Li}_{2} \mathrm{CO}_{3}$ と $\mathrm{TiO}_{2}$ の混合物を $700^{\circ} \mathrm{C}$ で 20 時間熱処理後 $1000^{\circ} \mathrm{C}$ で 焼結している例 ${ }^{16)}$ があるように高温を要する。本研究では低 温, 短時間でこれを得ることが出来た. Fig.6に pH11.8の混 合溶液から得られた沈殿物の熱処理後のSEM 写真を示す. $400{ }^{\circ} \mathrm{C}$ の加熱で約 $30 \sim 60 \mathrm{~nm}$ の微粒子が観察され, $1000^{\circ} \mathrm{C}$ での加熱の結果, 約 $0.15 \sim 3 \mu \mathrm{m}$ の粒子に成長した.

以上, 過剩な $\mathrm{LiOH}$ 溶液に $\mathrm{Ti}\left(\mathrm{SO}_{4}\right)_{2}$ 溶液を加えることで, $\mathrm{Li}$ を含んだ中間生成物が得られた．これを $500^{\circ} \mathrm{C} て ゙$ 加熱するこ とより, $\mathrm{Li}_{2} \mathrm{TiO}_{3}$ を主生成物とするナノサイズの粒子を作製す ることができた.

\section{$3.4 \mathrm{Na}_{2} \mathrm{O}-\mathrm{TiO}_{2}$ 系微粒子の作製}

同様にM=Naについての実験も行った. 沈殿物の加熱によ る結晶化について調べるため, TG-DTA測定および粉末 X線 回折法により, 沈殿物の熱処理後に得られる生成物の同定を 行った. Fig.7に pH 11.3の混合溶液から得られた沈殿物の TG-DTA 曲線を示す. TG曲線によると $100^{\circ} \mathrm{C}$ 付近で大きく 重量変化した後, $400,700^{\circ} \mathrm{C}$ 付近でもわずかに重量变化した. $800^{\circ} \mathrm{C}$ の加熱で $13 \%$ 重量減少した. DTA曲線から $100 \sim 200^{\circ} \mathrm{C}$ にかけて脱水, $400^{\circ} \mathrm{C}$ 付近で $\mathrm{OH}$ 基の脱離が起こったと考え

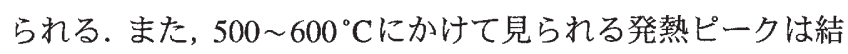
晶化によるものであり, この場合 $600^{\circ} \mathrm{C}$ でアルファスから 結晶化すると考えられる. Fig. 8 に沈殿物を $400,600,800^{\circ} \mathrm{C}$ および $1000^{\circ} \mathrm{C}$ で熱処理した後の粉末 $\mathrm{X}$ 線回折図形を示す. $1000^{\circ} \mathrm{C}$ 加熱による主生成物は $\mathrm{Na}_{2} \mathrm{O}-3 \mathrm{TiO}_{2}$ (31-1329 (JCPDS)) と $\mathrm{Na}_{2} \mathrm{O}-6 \mathrm{TiO}_{2}(37-951$ (JCPDS)) の二相と同定された. Sauvet 等はゾルゲル法によるチタン酸ナトリウムの作製において, $\mathrm{Na}$ 源に水酸化ナトリウムを使用した場合, $1000^{\circ} \mathrm{C}, 4 \mathrm{~h}$ の加熱 で $\mathrm{Na}_{2} \mathrm{Ti}_{3} \mathrm{O}_{7}$ の単一相, $1100^{\circ} \mathrm{C}, 4 \mathrm{~h}$ の加熱で $\mathrm{Na}_{2} \mathrm{O}-3 \mathrm{TiO}_{2}$ と 


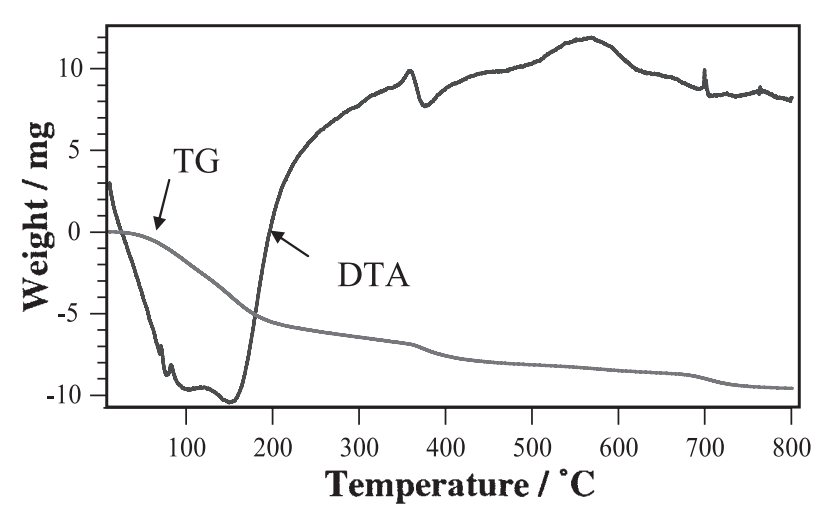

Fig.7 TG-DTA curves for the $\mathrm{Na}_{2} \mathrm{O}-\mathrm{TiO}_{2}$ precipitate obtained at room temperature.

Precipitation parameters:

$\mathrm{Ti}\left(\mathrm{SO}_{4}\right)_{2}$ solution: $0.1 \mathrm{~mol} / \mathrm{L}, 100 \mathrm{~mL}$

$\mathrm{NaOH}$ solution: $1.0 \mathrm{~mol} / \mathrm{L}, 100 \mathrm{~mL}$

pH after mixing: 11.3

TG-DTA measurement;

Sample weight: $57.1 \mathrm{mg}$

Heating up to $800^{\circ} \mathrm{C}$ with $5^{\circ} \mathrm{C} / \mathrm{min}$.

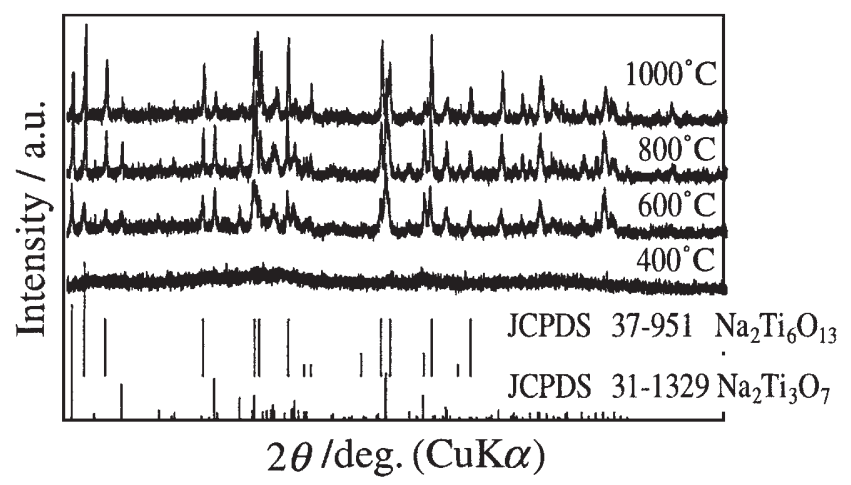

Fig.8 XRD patterns for the $\mathrm{Na}_{2} \mathrm{O}-\mathrm{TiO}_{2}$ precipitate after heating at different temperatures.

Precipitation parameters:

$\mathrm{Ti}\left(\mathrm{SO}_{4}\right)_{2}$ solution: $0.1 \mathrm{~mol} / \mathrm{L}, 100 \mathrm{~mL}$

$\mathrm{NaOH}$ solution: $1.0 \mathrm{~mol} / \mathrm{L}, 100 \mathrm{~mL}$

pH after mixing: 11.3

$\mathrm{Na}_{2} \mathrm{O}-6 \mathrm{TiO}_{2}$ の二相であると報告している ${ }^{5)}$. 溶液プロセスで は $\mathrm{M}=\mathrm{K}, \mathrm{Li}$ の場合においても，沈殿物を $1000^{\circ} \mathrm{C}$ 加熱後に得 られる生成物の組成は, 沈殿物の組成比に関わらず決まって おり, $\mathrm{M}=\mathrm{Na}$ の場合も, 得られた沈殿物は $\mathrm{Na}_{2} \mathrm{Ti}_{3} \mathrm{O}_{7} や \mathrm{Na}_{2} \mathrm{Ti}_{6} \mathrm{O}_{13}$ になりうる前駆体粉末であると考えられる. Fig.9にpH 10の 混合溶液から得られた沈殿物の熱処理後のSEM写真を示す. $400^{\circ} \mathrm{C}$ で約 $100 \mathrm{~nm}$ 二次粒子が観察された. $1000^{\circ} \mathrm{C}$ までの加 熱で粒子の成長が観察された。

以上, 過剰な $\mathrm{NaOH}$ 溶液に $\mathrm{Ti}\left(\mathrm{SO}_{4}\right)_{2}$ 溶液を加えることで, $\mathrm{Na}$ を含んだ中間生成物が得られた。これを $600^{\circ} \mathrm{C} て ゙$ 加熱するこ とより, $\mathrm{Na}_{2} \mathrm{Ti}_{3} \mathrm{O}_{7}$ と $\mathrm{Na}_{2} \mathrm{Ti}_{6} \mathrm{O}_{13}$ を主生成物とする粒子を作製す ることができた。

\section{$3.5 \mathrm{M}_{2} \mathrm{O}-\mathrm{TiO}_{2}(\mathrm{M}=\mathrm{K}, \mathrm{Li})$ 系薄膜の作製}

我々は以前から溶液プロセスを用いて, $\mathrm{TiO}_{2}$ 等の単成分系 の各種酸化物薄膜の作製を試みてきた.これは原料溶液を直

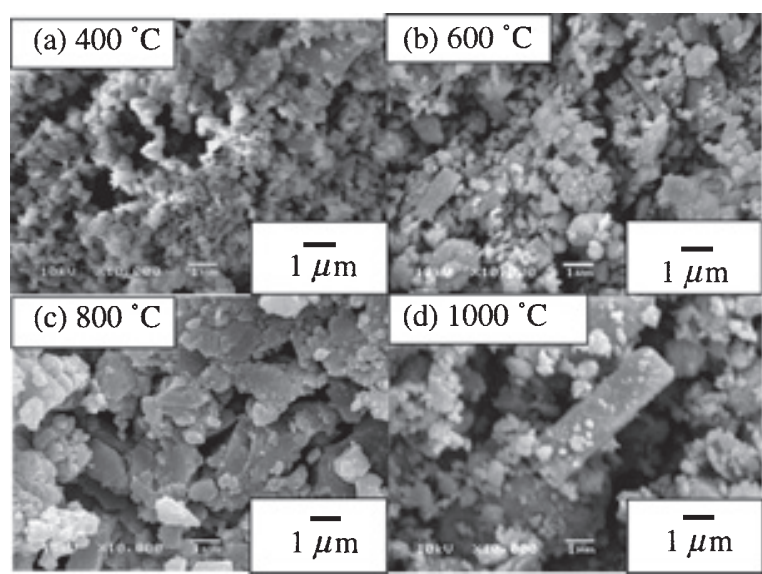

Fig.9 SEM image of the $\mathrm{Na}_{2} \mathrm{O}-\mathrm{TiO}_{2}$ precipitate after heating at $400^{\circ} \mathrm{C}$.

Precipitation parameters:

$\mathrm{Ti}\left(\mathrm{SO}_{4}\right)_{2}$ solution: $0.1 \mathrm{~mol} / \mathrm{L}, 100 \mathrm{~mL}$

$\mathrm{NaOH}$ solution: $1.0 \mathrm{~mol} / \mathrm{L}, 100 \mathrm{~mL}$ pH after mixing: 11.3

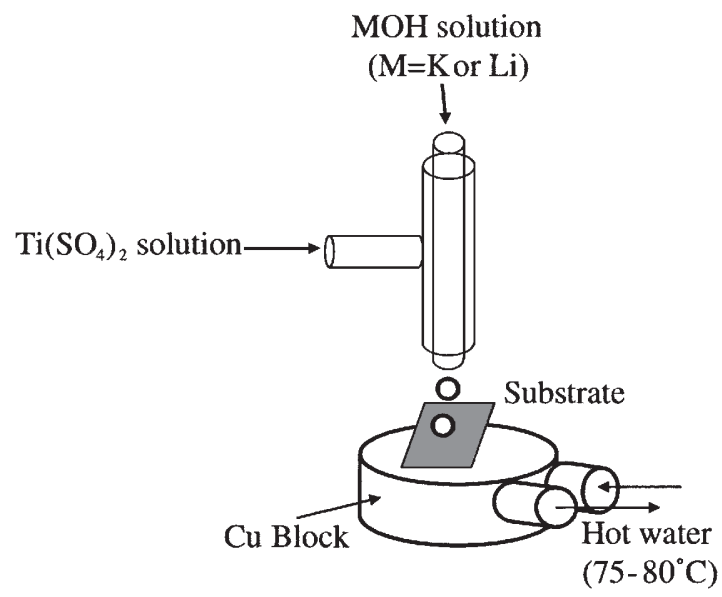

Fig.10 Schematic illustration of the deposition of $\mathrm{M}_{2} \mathrm{O}-\mathrm{TiO}_{2}$ thin film by solution process

接 $\mathrm{Si}$ 基板上に滴下し, 基板表面で反応を起こすことで $\mathrm{Si}$ 基板 上に微細な粒子が堆積し, 室温または $100^{\circ} \mathrm{C}$ 以下の低温で薄 膜を得る方法である.この方法は, 成膜の低エネルギ一化, 非 耐熱材料へ成膜可能になることを狙ったものである.さらに 我々はこの溶液プロセスを用いた薄膜作製方法の適用範囲を 広げるべく，2成分系の薄膜作製を試みた。しかし，緒言で も述べたように, 水溶液からアルカリ金属を含む固体化合物 をつくることは困難であることから，2 成分系薄膜の作製に は至っていない. そこで 3.1 で得られた含アルカリ沈殿物の 作製条件を参考にチタンおよびアルカリ金属の 2 成分を含む 薄膜が作製できれば， 2 成分系薄膜作製のための基礎的な デー夕になると考えられる。この項では室温近くの低温で, チタンとアルカリ金属の 2 成分を含む薄膜を作製することを 目的として実験した。

まず, $\mathrm{Si}$ 基板を $6 \mathrm{~N}-\mathrm{HCl}$ に約 6 時間浸し, 油脂や污れを洗 浄した. $\mathrm{Ti}\left(\mathrm{SO}_{4}\right)_{2}$ 溶液および $\mathrm{MOH}(\mathrm{M}=\mathrm{K}, \mathrm{Li})$ を Fig.10に示す 
装置を用い，それぞれ直接基板上に滴下し，薄膜作製を試み た.この際，基板上の温度を $75 \sim 85^{\circ} \mathrm{C}$ に保った. Table 2 に $\mathrm{K}_{2} \mathrm{O}-\mathrm{TiO}_{2}$ 系酸化物薄膜の作製条件, Table 3 に $\mathrm{Li}_{2} \mathrm{O}-\mathrm{TiO}_{2}$ 系酸 化物薄膜の作製条件を示す. $\mathrm{Ti}\left(\mathrm{SO}_{4}\right)_{2}$ 溶液に比べ $\mathrm{MOH}$ 溶液の 濃度を 10 倍程度濃くし, 滴下直後の溶液の $\mathrm{pH}$ がアルカリ性 を示すように各溶液の流量を調整した. Fig.11 (a)に得られた $\mathrm{K}_{2} \mathrm{O}-\mathrm{TiO}_{2}$ 系酸化物薄膜, および Fig. 11 (b) に $\mathrm{Li}_{2} \mathrm{O}-\mathrm{TiO}_{2}$ 系薄膜 の表面写真を示す. 作製した薄膜の表面には干渉膜の生成が 観察された. Fig.12に(a) $\mathrm{K}_{2} \mathrm{O}-\mathrm{TiO}_{2}$ 系酸化物薄膜(b) $\mathrm{Li}_{2} \mathrm{O}-\mathrm{TiO}_{2}$ 系薄膜の SEM 写真示す。薄膜は約 $100 \mathrm{~nm}$ の粒子から成って いた. クロスカットテープテストによる密着性試験では薄膜
の密着性は良好，モース硬度測定による薄膜の硬度は 3 で あった. また ICP分析により薄膜中の組成は $\mathrm{K}_{2} \mathrm{O}: \mathrm{TiO}_{2}=1: 10$, $\mathrm{Li}_{2} \mathrm{O}: \mathrm{TiO}_{2}=1: 1$ (モル比) 程度であり, チタンとアルカリ金 属を含む薄膜を作製することができた. しかし，この薄膜に は水や $\mathrm{OH}$ 基が含まれていると考えられる，ICPによる組成 分析において,3.1で作製した沈殿物よりも薄膜のほうがチ夕 ンの量に対して含まれるアルカリ金属は少なかった。これは 沈殿物を作製した際は $\mathrm{MOH}$ 溶液に $\mathrm{Ti}\left(\mathrm{SO}_{4}\right)_{2}$ 溶液を滴下して いったのに対し，薄膜を作製する際は原料溶液をそれぞれ一 緒に基板上に滴下したため, 含まれるアルカリ金属の量に差 が出たと考えられる．また，この薄膜を沈殿物が結晶化する

Table 2 Deposition parameters for $\mathrm{K}_{2} \mathrm{O}-\mathrm{TiO}_{2}$ thin film.

\begin{tabular}{|c|c|c|c|}
\hline & $\mathrm{KOH}$ concentration & $\mathrm{Ti}\left(\mathrm{SO}_{4}\right)_{2}$ concentration & \multirow[t]{2}{*}{$\mathrm{pH}$ after mixing } \\
\hline & Flow rate & Flow rate & \\
\hline \multirow[t]{2}{*}{1} & $1.0 \times 10^{-2} \mathrm{~mol} / \mathrm{L}$ & $0.3 \times 10^{-2} \mathrm{~mol} / \mathrm{L}$ & \multirow[t]{2}{*}{$5.0 \sim 7.0$} \\
\hline & $20 \mathrm{~mL} / \mathrm{min}$ & $20 \mathrm{~mL} / \mathrm{min}$ & \\
\hline \multirow[t]{2}{*}{2} & $1.0 \times 10^{-2} \mathrm{~mol} / \mathrm{L}$ & $1.0 \times 10^{-2} \mathrm{~mol} / \mathrm{L}$ & \multirow[t]{2}{*}{$5.0 \sim 7.0$} \\
\hline & $30 \mathrm{~mL} / \mathrm{min}$ & $6 \mathrm{~mL} / \mathrm{min}$ & \\
\hline \multirow[t]{2}{*}{3} & $1.0 \times 10^{-2} \mathrm{~mol} / \mathrm{L}$ & $0.3 \times 10^{-2} \mathrm{~mol} / \mathrm{L}$ & \multirow[t]{2}{*}{$8.0 \sim 9.0$} \\
\hline & $30 \mathrm{~mL} / \mathrm{min}$ & $6 \mathrm{~mL} / \mathrm{min}$ & \\
\hline
\end{tabular}

Table 3 Deposition parameters for $\mathrm{Li}_{2} \mathrm{O}-\mathrm{TiO}_{2}$ thin film.

\begin{tabular}{|c|c|c|c|}
\hline & $\mathrm{LiOH}$ concentration & $\mathrm{Ti}\left(\mathrm{SO}_{4}\right)_{2}$ concentration & \multirow[t]{2}{*}{$\mathrm{pH}$ after mixing } \\
\hline & Flow rate & Flow rate & \\
\hline \multirow[t]{2}{*}{1} & $1.0 \times 10^{-2} \mathrm{~mol} / \mathrm{L}$ & $0.1 \times 10^{-2} \mathrm{~mol} / \mathrm{L}$ & \multirow[t]{2}{*}{$7.0 \sim 9.0$} \\
\hline & $30 \mathrm{~mL} / \mathrm{min}$ & $6 \mathrm{~mL} / \mathrm{min}$ & \\
\hline \multirow[t]{2}{*}{2} & $1.0 \times 10^{-2} \mathrm{~mol} / \mathrm{L}$ & $0.3 \times 10^{-2} \mathrm{~mol} / \mathrm{L}$ & \multirow[t]{2}{*}{$8.0 \sim 9.0$} \\
\hline & $30 \mathrm{~mL} / \mathrm{min}$ & $4 \mathrm{~mL} / \mathrm{min}$ & \\
\hline \multirow[t]{2}{*}{3} & $1.0 \times 10^{-2} \mathrm{~mol} / \mathrm{L}$ & $0.3 \times 10^{-2} \mathrm{~mol} / \mathrm{L}$ & \multirow[t]{2}{*}{$7.0 \sim 9.0$} \\
\hline & $16 \mathrm{~mL} / \mathrm{min}$ & $2 \mathrm{~mL} / \mathrm{min}$ & \\
\hline
\end{tabular}

(a)

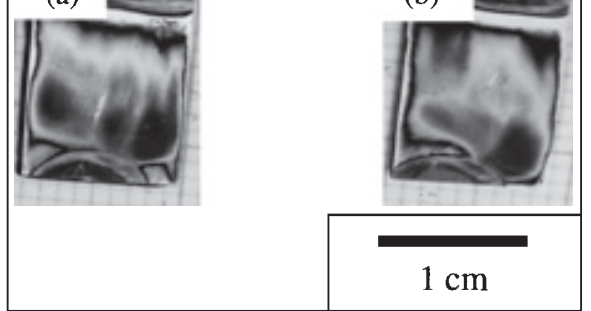

Fig.11 Appearances of the thin film obtained by dripping the mixed solution. (a) $\mathrm{K}_{2} \mathrm{O}-\mathrm{TiO}_{2}$ (b) $\mathrm{Li}_{2} \mathrm{O}-\mathrm{TiO}_{2}$

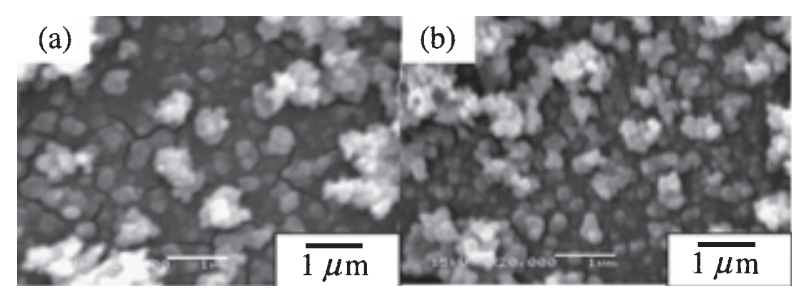

Fig.12 SEM image of the thin film obtained by dripping the mixed solution. Deposition parameters: Condition 3 listed in Tables 2 or 3. (a) $\mathrm{K}_{2} \mathrm{O}-\mathrm{TiO}_{2}$ (b) $\mathrm{Li}_{2} \mathrm{O}-\mathrm{TiO}_{2}$ 
$500^{\circ} \mathrm{C}$ で加熱したところ，薄膜を構成する粒子が凝集し，膜 中に亀裂が生じ, 薄膜形状が破壊されてしまう問題があった. 薄膜化においてはさらなる検討が必要であるが，本研究で $\mathrm{M}_{2} \mathrm{O}-\mathrm{TiO}_{2}$ 系沈殿物を作製し，その生成条件からアルカリ金属 を含む薄膜を作製することができた．

\section{4 結言}

本研究では, 水溶液からのチタン酸アルカリ酸化物微粒子 の作製を目的として, チタン酸アルカリの生成に対する反応 条件の検討を行い，以下の結果を得た。

(1) $\mathrm{M}(=\mathrm{K}, \mathrm{Li}, \mathrm{Na}): \mathrm{Ti}=10: 1$ (モル比) と, 水酸化アルカリ溶 液がかなり過剩である場合, チタンを含む沈殿物中にア ルカリを含有させることが出来た.

(2) $400^{\circ} \mathrm{C}$ 低温における熱処理により,チタン酸アルカリの $20 \sim 30 \mathrm{~nm}$ 程の粒子からなるナノ粒子を得ることが出来 た. 生成相として $\mathrm{M}=\mathrm{K}$ の場合, $\mathrm{K}_{2} \mathrm{O}-6 \mathrm{TiO}_{2}, \mathrm{M}=\mathrm{Li}$ の場 合, $\mathrm{Li}_{2} \mathrm{O}-\mathrm{TiO}_{2}, \mathrm{M}=\mathrm{Na}$ の場合 $\mathrm{Na}_{2} \mathrm{O}-3 \mathrm{TiO}_{2}$ と $\mathrm{Na}_{2} \mathrm{O}-6 \mathrm{TiO}_{2}$ の 2 相が得られた。

(3) $\mathrm{Si}$ 基板に溶液を滴下する方法で薄膜化について検討した 結果, $\mathrm{Ti}\left(\mathrm{SO}_{4}\right)_{2}$ 溶液に対して, 高濃度の $\mathrm{MOH}(\mathrm{M}=\mathrm{K}, \mathrm{Li})$ 溶 液を流量過剩に供給した場合, $\mathrm{Si}$ 基板上に, およそ $100 \mathrm{~nm}$ の粒子が堆皘した薄膜を得ることができた，生成膜はそ れぞれ，組成比 $\mathrm{K}_{2} \mathrm{O}: \mathrm{TiO}_{2}=1: 10, \mathrm{Li}_{2} \mathrm{O}: \mathrm{TiO}_{2}=1: 1$ (モル 比)であり, 膜中に $\mathrm{H}_{2} \mathrm{O}$ またはOH基を含むものであった.

\section{文献}

1) Y. Asada, K. Fujimoto, and S. Ito: "Deposition parameters and micro-structure in the $\mathrm{TiO}_{2}$ thin film prepared by dripping an aqueous solution", Proc. $114^{\text {th }}$ Conference of the Surface Finishing Society of Japan, (2006) 138.

2) J. Barket: "In-situ measurement of the thickness changes associated with cycling of prismatic lithium ion batteries based on $\mathrm{LiMn}_{2} \mathrm{O}_{4}$ and $\mathrm{LiCoO}_{2}$ ", Electrochimica Acta, 45(1999)235-242.

3) K. Fujimoto, S. Ito, and M. Watanabe: "Crystal growth and refinement of $\mathrm{K}_{1.88} \mathrm{Ga}_{1.88} \mathrm{Sn}_{8.12} \mathrm{O}_{16}$ hollandite-type compound", Solid State Ionics, 177(2006)1901-1904.

4) T. Hattori and M. Ishigame: "Electronic band structures of and ionic conduction in $\beta$-alumina type superionic conductors", Solid State Ionics, 109(1998)197-205.

5) A-L. Sauvet, S. Baliteau, C. Lopez, and P. Fabry: "Synthesis and characterization of sodium titanates $\mathrm{Na}_{2} \mathrm{Ti}_{3} \mathrm{O}_{7}$ and $\mathrm{Na}_{2} \mathrm{Ti}_{6} \mathrm{O}_{13}{ }^{\prime \prime}, \mathrm{J}$. Solid State Chem., 177(2004)4508-4515.

6) A.D. Wadsley and W.G. Mumme: "The Crystal Structure of $\mathrm{Na}_{2} \mathrm{Ti}_{7} \mathrm{O}_{15}$, an Ordered Intergrowth of $\mathrm{Na}_{2} \mathrm{Ti}_{6} \mathrm{O}_{13}$ and $\mathrm{Na}_{2} \mathrm{Ti}_{8} \mathrm{O}_{17}$, Acta Cryst., B24(1968)392.

7) M. Dion, Y. Piffard, and M. Tournoux: "The tetratitanates $\mathrm{M}_{2} \mathrm{Ti}_{4} \mathrm{O}_{9}(\mathrm{M}=\mathrm{Li}, \mathrm{Na}, \mathrm{K}, \mathrm{Tl}, \mathrm{Ag}) "$, J. Inorg. Nucl., 40(1978)918919.

8) H. Izawa, S. Kikkawa, and M. Koizumi: "Effect of Intercalated Alkylammonium on Cation Exchange Properties of $\mathrm{H}_{2} \mathrm{Ti}_{3} \mathrm{O}_{7}$ ", J. Solid State Chem., 69(1987)336-342.

9) M. Holzinger, J. Maier, and W. Sitte: "Potentiometric detection of complex gases: Application to $\mathrm{CO}_{2}$ ", Solid State Ionics, 94 (1997)217-225.

10) G.H. Du, Q. Chen, P.D. Han, Y. Yu, and L.M. Peng: "Potassium titanate nanowires: Structure, growth, and optical properties", Physical Review B, 67(2003)035323.

11) S.C. Tjong and Y.Z. Meng: "Properties and morphology of polyamide 6 hybride composities containing potassium titanate whisker and liquid crystalline copolyester", Polymer, 40(1999) 1109-1117.

12) B.L. Wang, Q. Chen, R.H. Wang, and L.M. Peng: "Synthesis and characterization of $\mathrm{K}_{2} \mathrm{Ti}_{6} \mathrm{O}_{13}$ nanowires", Chemical Physics Letters, 376(2003)726-731.

13) D. Yu, J. Wu, L. Zhou, D. Xie, and S. Wu: "The dielectric and mechanical properties of a potassium-titanate-whiskerreinforced PP/PA blend", Composites Science and Technology, 60(2000)499-508.

14) N. Bao, X. Feng, X. Lu, and Z. Yang: "Study on the formation and growth potassium titanate whiskers", J. Mater. Sci., 37 (2002)3075-3043.

15) J. P. Kopasz, J. M. Miller, and C. E. Jonson: "Tritium release from lithium, a low-activation tritium breeding material", Journal of Nuclear Materials, 212-215(1994)927-931.

16) Th. Fehr and E. Schmidbauer: "Electrical conductivity of $\mathrm{Li}_{2} \mathrm{TiO}_{3}$ ceramics", Solid State Ionics., 178(2007)35-41.

17) B. Wang, Y. Shi, and D. Xue: "Large aspect ratio titanate nanowire prepared by monodispersed titanate submicron sphere via simple wet-chemical reactions", J. Solid State Chem., 180 (2007) 1028-1037. 